\title{
DOES CRIME AFFECT FIRM PERFORMANCE: EVIDENCE FROM POST-TRANSITION ECONOMIES
}

\author{
Valerija Botric ${ }^{*}$
}

\begin{abstract}
The paper addresses the relatively unexplored issue of the effects of crime against business on firm performance in post-transition economies. The focus is on the eight countries: Bosnia and Herzegovina, Bulgaria, Croatia, Czechia, Montenegro, Serbia, Slovakia, and Slovenia. Based on the comparable microdata from World Bank Enterprise Survey the analysis shows that respondents in firms who suffered crime losses are in general more likely to expect a decrease in their sales in the next fiscal period. It has been also established that in some countries those who experienced crime losses are more optimistic about the possibility to increase the sales in the short-run (Slovakia, Montenegro, and Croatia), thus indicating certain resilience to adverse effects of crime. The estimates of the multinomial model suggest that crime exposure negatively affects business activity. However, the effect was only significant for those who expect decreases in their activity - respondents who experienced losses attributed to crime are $5.9 \%$ more likely to expect a decrease in their future sales (in comparison to maintain the same level of sales).
\end{abstract}

KEYWORDS: crime against firms, firm performance, post-transition economies

\section{INTRODUCTION}

The adverse effects of crime on economic activity are widely acknowledged. While it is not straightforward that criminal activity in a specific region will dampen the entrepreneurship potential, it has the potential to adversely affect human capital, leading to gaps in productivity and innovation and subsequently reducing economic growth potential. It is very likely that firms will restrain from investing in crime-affected areas, contributing to poverty increases, and

\footnotetext{
Valerija Botrić, The Institute of Economics, Zagreb, Croatia; vbotric@eizg.hr.
} 
supporting the local population's perception of crime as the only viable survival option. This mechanism creates pockets with intense crime activity, where policymakers struggle to create effective measures needed to revive regular economic activity.

However, crime is not restricted to these enclaves and through its many forms influences the daily lives around the globe. Violent crimes can influence local businesses indirectly through detrimental influence on the firms' employees (thus reducing their productivity potential), certain activities of organized crime can be arranged through informal competition on the market (thus reducing regular businesses growth and profit potential), while the perception of a region to be highly crime inflected can deter potential investors. The crime that affects firms directly - such as fraud, Internet-related crime, industrial espionage, terrorist acts against business leaders - usually catch little public attention. The costs imposed on affected firms are, nevertheless, high and have an impact beyond the visible balance sheet effects. ${ }^{1}$ Regardless, research efforts on exploring the effects of crime on business activity are relatively rare.

Contrary to some other segments of the world, in post-transition European societies crime is not considered a major obstacle for entrepreneurship. Indeed, World Bank data shows that it usually falls behind other problems faced by entrepreneurs - informal sector, high taxes, or inadequately educated workforce. ${ }^{2}$ Although existing studies point that security costs exceed the research and development expenditures in transition economies, ${ }^{3}$ research efforts are seldom directed towards exploring crime as an important business obstacle.

The paper's main contribution is addressing this gap in the literature for post-transition societies. The analysis is focused on eight Central and South-Eastern European countries: Bosnia and Herzegovina, Bulgaria, Croatia, Czechia, Montenegro, Serbia, Slovakia, and Slovenia. Furthermore, the analysis complements the more general literature on the effects of crime on firm performance by focusing on an alternative measure of firm performance - expectations about future firm growth.

1 PwC: Fighting fraud: A never ending tale. PwC's Global Economic Crime and Fraud Survey, [https://www.pwc.com/gx/en/forensics/gecs-2020/pdf/global-economic-crime-and-fraudsurvey-2020.pdf], accessed 10/08/2020, 2020, p. 7.

2 Among the analysed countries in this paper, for the year 2019 the major business obstacles reported by respondents were practices of the informal sector (Bulgaria, Montenegro and Serbia), tax rates (Croatia and Slovakia), inadequately educated workforce (Czechia and Slovenia) and political instability (Bosnia and Herzegovina). https://www.enterprisesurveys.org/en/data/ exploretopics/biggest-obstacle

Amin, M.: Crime, Security and Firms in Latin America (Short Note), [http://works.bepress.com/mohammad_amin/11], accessed 03/06/2020,p. 1. 
The paper adopts the following structure. The next section briefly presents relevant literature. Section 3 discusses the methodology and the data sources used in the empirical analysis, presented in Section 4. The last section offers conclusions.

\section{LITERATURE REVIEW}

Crime has many effects on society and is more likely to be the topic of interest in criminology, psychology, or sociology than economics. However, economists have started putting more emphasis on the effects of crime on economic activity since the seminal work by Becker. ${ }^{4}$ Becker's theoretical model envisages crime as a type of economic activity, in which an economic agent decides to participate in based on the evaluation of related costs and benefits. When considering costs, an agent necessarily includes the estimation of the punishment costs (related to the probability of apprehension), while punishment also enters the public policies domain where its optimal level is determined in a way to minimize social loss related to crime. So, a particular level of crime in a society is a result of an interaction of both private and public decision-making processes, leading to cross-country and cross-regional differences in crime rates.

In these differences between countries, certain economic factors also play important roles. Literature has suggested high unemployment and poverty rates, the share of the private sector as well as the structural composition of the economy as important explanations for differences in crime rates across the countries. ${ }^{5}$ These factors are likely to affect any type of crime, although not always in the same way. For example, street crime is expected to increase with the rise of unemployment, because during times of economic hardships economic agents perceive increased benefits and lower opportunity costs of engaging in criminal activity. ${ }^{6}$ Organized crime can follow the procyclical path, as persons engaged in some organized crime activities (such as drug trafficking) frequently have legitimate employment careers. The retail sector is prone to theft, while the private sector is exposed to extortion.

4 Becker, G.: Crime and Punishment: An economic approach, Journal of Political Economy, 76(1) 1968, p. 160-217.

5 Krkoska, L.; Robeck, K.: The impact of crime on the enterprise sector: Transition versus non-transition countries, EBRD Working Paper No. 97, 2006, p.21.

6 Rocque, M. et al.: Revisiting the Relationship Between the Economy and Crime: The Role of the Shadow Economy, Justice Quarterly, 36(4) 2019, p. 647.

7 Freeman, R.B.: The Economics of Crime, in: Ashenfelter, O.C.; Card, D. (eds.): Handbook of Labor Economics, Volume 3, Part C, Amsterdam, Netherlands: North Holland Publishers, 1999, p. 3543-3544. 
The present analysis is focused on the relatively unexplored issue in the literature, i.e. the effects of crime on business activity. In general, the local environment a firm operates in has the possibility to create agglomeration externalities that can reduce costs, increase efficiency and firm growth. ${ }^{8}$ Firms that operate in high crime rates areas seem more likely to incorporate some form of illegal operations, such as tax avoidance or earnings management, into their business agenda. ${ }^{9}$ The crime-affected regions are also the regions with increased poverty, thus further increase in crime activity additionally decreases local demand. ${ }^{10}$ This effect of crime could be particularly severe for specific economic activities if customers fear that they will be victimized when making specific purchases. Islam ${ }^{11}$ finds the important relationship between a crime against firms and economic growth that is particularly detrimental for small and medium-sized firms. The study argues for pro-growth economic policies, suggesting they might be also beneficial for crime reduction policy targets.

One of the most deterring effects of crime is on the investment decision-making process. ${ }^{12}$ When firms postpone their investment decisions because of concern that benefits will be expropriated, it dampens the overall growth potential. Business operations in crime-infested regions usually incur higher security costs, ${ }^{13}$ regardless of whether firms engage additional security guards or invest in additional equipment, such as security cameras. Crime activity can create disruptions in supply chains, ${ }^{14}$ negatively affecting sales and profits.

Thus, an important concern is related to the effect the crime has on productivity, regardless of whether it affects a firm's inability to sell products or increases its costs. For example, exposure to crime can raise labour costs, in

8 Baldwin, J. R. et al.: Agglomeration economies: Microdata panel estimates from Canadian manufacturing, Journal of Regional Science, 50(5) 2010, p.932.

9 Cho, H. et al.: Regional crime rates and corporate misreporting, Spanih Journal of Finance and Accounting/Revista Española Financiación Contabilidad, 49(1) 2020, p.117.

10 Greenbaum, R.T. et al.: The Impact of Terrorism on Italian Employment and Business Activity, Urban Studies 44(5/6) 2007, p.1093-1108.

11 Islam, A.: Economic growth and crime against small and medium sized enterprises in developing economies, Small Business Economics, 43(3) 2014, p.688.

12 Ben-Yishay, A.; Pearlman, S.: Crime and Microenterprise Growth: Evidence from Mexico, World Development, 56 2014, p. 139-152; Gaviria, A.: Assessing the effects of corruption and crime on firm performance: evidence from Latin America, Emerging Markets Review, 3(2) 2002, p.245-268.

13 Czinkota, M.R. et al.: Terrorism and International Business: A Research Agenda, Journal of International Business Studies, 41(5) 2010, p.826-843.

14 Barnes, P.; Oloruntoba, R.: Assurance of Security in Maritime Supply Chains: Conceptual Issues of Vulnerability and Crisis Management, Journal of International Management, 11(4) 2005, p. 519-540. 
cases when workers face increased security risks. ${ }^{15}$ The specific way the crime affects productivity depends on the type of crime faced by the firm. Theft is more likely to increase costs, while violent crime in a region is more likely to disrupt supply chains and/or reduce sales. Albanese and Marinelli ${ }^{16}$ based on an Italian example document that organized crime negatively affects firm productivity, and the results are robust to firms of different sizes and different economic sectors.

Less thought of crime effects on business activity, but still highly relevant in some regions are extortion charges. ${ }^{17}$ These are usually directed towards firms' management. Although it is not always the case that firms bear the costs directly, such activity can increase the insurance costs against similar cases or could affect the decision-making process in the firm, creating disruptions in business operations.

When exploring the effects of crime against enterprises, the characteristics of firms exposed to crime come into focus. Effects of crime on the economic activity of the firms are versatile, although not adversely universal, as according to some studies it mostly depends on locations and economic sectors. ${ }^{18}$ Firm's size, ownership structure, whether it belongs to a sector likely targeted by crime $^{19}$ are usual factors when considering if an enterprise will be exposed to crime directly. There is also evidence that female-owned households, as well as female-owned firms, have a positive association with higher crime rates. ${ }^{20}$

Post-transition economies are seldom explored in this context in the literature, the literature is rather focused on other regions more affected by criminal activity. Early studies on the transformation of the formerly communist into

15 Jaitman, L. (ed.): The cost of crime and violence: new evidence and insights in Latin America and the Caribbean, New York: Inter-American Development Bank, 2017, p.8.

16 Albanese, G.; Marinelli, G.: Organized crime and productivity: Evidence from firm-level data, Rivista Italiana degli Economisti, 18 2013, p.367-394.

17 Daniele, V.; Marani, U.: Organized Crime, the Quality of Local Institutions and FDI in Italy: A Panel Data Analysis, European Journal of Political Economy, 27(1) 2011, p.135.

18 Rosenthal, S.; Ross, A.: Violent Crime, Entrepreneurship, and Cities, Journal of Urban Economics, 67(1) 2010, p.140.

19 Amin, M.: Crime, Security and Firms in Latin America (Short Note), [http://works.bepress.com/mohammad_amin/11], accessed 03/06/2020; Krkoska, L.; Robeck, K.: The impact of crime on the enterprise sector: Transition versus non-transition countries, EBRD Working Paper No. 97, 2006.

20 Islam, A.: Is There a Gender Bias in Crime Against Firms in Developing Economics?, Women's Studies International Forum, 37 2013, p.1-15; Islam, A.: Economic growth and crime against small and medium sized enterprises in developing economies, Small Business Economics, 43(3) 2014, p.682; Kelly, M.: Inequality and Crime, Review of Economics and Statistics, 82 (4) 2000, p.535. 
market economies frequently focused on the problems related to privatization. It has been argued that privatization opened opportunities for theft, an unlawful profit, corruption, illicit pressure on the legislature and executive bodies, as well as organized extortion and protection rackets. ${ }^{21}$ Some studies find that criminal activities increased after the collapse of the former system, because of swift changes in law enforcement institutions, rapidly shifting economic regulations, and changes in social psychology. ${ }^{22}$ However, others claim that throughout the socialist system organized crime was concealed within the criminal-political nexus. ${ }^{23}$ Economic conditions contributed to the creation and maintenance of the relationship because constant economic shortages led to the creation of the black market. At the same time, bribery was considered necessary to secure basic goods and services, leading to widespread corruption still prevalent in some post-transition economies. For example, Bjelalac and Bingulac $^{24}$ argue that in Serbia bribery has become a necessary condition for even the smallest business enterprise to maintain its operation on the market.

Regardless of the joint European Union efforts to prevent criminal activities, ${ }^{25}$ some studies argue that the very same factors that have encouraged the freedom of movement of goods and people, and that have promised greater human rights and quality of life throughout Europe, have also potential to stimulate activities of organized crime. ${ }^{26}$ So, the transformation of the societies in the early phases of transition and joining the European Union in the post-transition period are factors that could have potentially increased crime exposure of enterprises in the economies at the same time struggling to achieve economic convergence towards the EU average.

European post-transition economies are for the most part also EU members. Those analyzed in this paper are either members (Bulgaria, Croatia, Czechia, Slovakia, and Slovenia) or have achieved the status of candidates (Bosnia and Herzegovina, Montenegro, and Serbia). An important part of the EU accession is improvement in government effectiveness and regulatory quality usually

${ }_{21}$ Los, M.: Crime in transition: The post-communist state, markets and crime, Crime, Law and Social Change, 40(2-3) 2003, p.147.

22 Lotspeich, R.: Crime in transition economies, Europe-Asia Studies, 47(4) 1995, p.564.

23 Hignett, K.: Organised Crime in East Central Europe: The Czech Republic, Hungary and Poland, Global Crime, 6(1) 2004, p.71.

24 Bjelalac, Ž.; Bingulac, N.: Impact of corruption on the process of Eurointegration of Serbia, Journal of Eastern-European Criminal Law, 1 2016, p.212.

25 https://ec.europa.eu/home-affairs/what-we-do/policies/organized-crime-and-human-trafficking/crime-prevention_en

26 Allum, F.; Sands, J.: Explaining organized crime in Europe: Are economists always right?, Crime, Law and Social Change, 41(2) 2004, p.137. 
monitored through the successful reform of the judiciary system. The quality of the judiciary system is important for the society's response to the criminal threat, and the accession process is not a guarantee of its successful transformation. ${ }^{27}$ Within the European Union, one of the important processes is economic convergence that is expected to benefit the citizens of member states. To enable the speed of catching up process in the post-transition societies, obstacles for entrepreneurship must be reduced. The rest of the paper is devoted to the analysis of one of the neglected obstacles in the literature of the post-transition countries catching-up process.

\section{DATA AND METHODOLOGY}

We analyze the effects of crime on enterprises in eight Central and South-Eastern European countries: Bosnia and Herzegovina, Bulgaria, Croatia, Czechia, Montenegro, Serbia, Slovakia, and Slovenia. The World Bank Enterprise Survey microdata has been used ${ }^{28}$ to address the effect of crime in a comparable way across the countries. The Survey respondents are business owners or top managers of registered companies with 5 or more employees, while firms with $100 \%$ government ownership are not included in the sample. Since the focus of the paper is on the effect of crime exposure on the business sector, the Survey offers a number of related questions. The most frequently cited in the literature is whether a respondent considers crime to be a major obstacle for the firm. However, in this case, the crime might not be directly related to the firm but could be a part of the general business environment. In order to be able to analyze specifically whether the firm is affected directly by criminal activity, we focus on the incidence of crime. Specifically, we refer to the question "did this establishment experience losses as a result of theft, robbery, vandalism, arson on this establishment's premises or from Internet hacking or fraudulent Internet transactions?" We acknowledge the fact that results depend on the willingness of the respondent to admit being a victim of crime, which some respondents might be reluctant to do. However, since negative victimization is more likely in crimes against persons and not businesses, and other comparable micro datasets across the analyzed countries are not available, we proceed

\footnotetext{
27 Spendzharova, A.B.; Vachudova, M.A.: Catching Up? Consolidating Liberal Democracy in Bulgaria and Romania after EU Accession, West European Politics, 35(1) 2012, p. 39-58.

28 Individual firm-level data is available for download at https://www.enterprisesurveys.org/. The Survey, also referred to as the Business Environment and Enterprise Performance Survey (BEEPS), has evolved through different waves, for years 1999, 2002, 2005, 2007, 2009, 2012, and 2019. The website, along with the data, contains all questionnaires and sample information data. Not all the countries were included in all the waves and the 2019 Survey results are not yet available for all participating countries.
} 
with the analysis. The percentages of respondents who positively answered the question are presented in Figure 1.

Figure 1 Percentage of firms exposed to crime

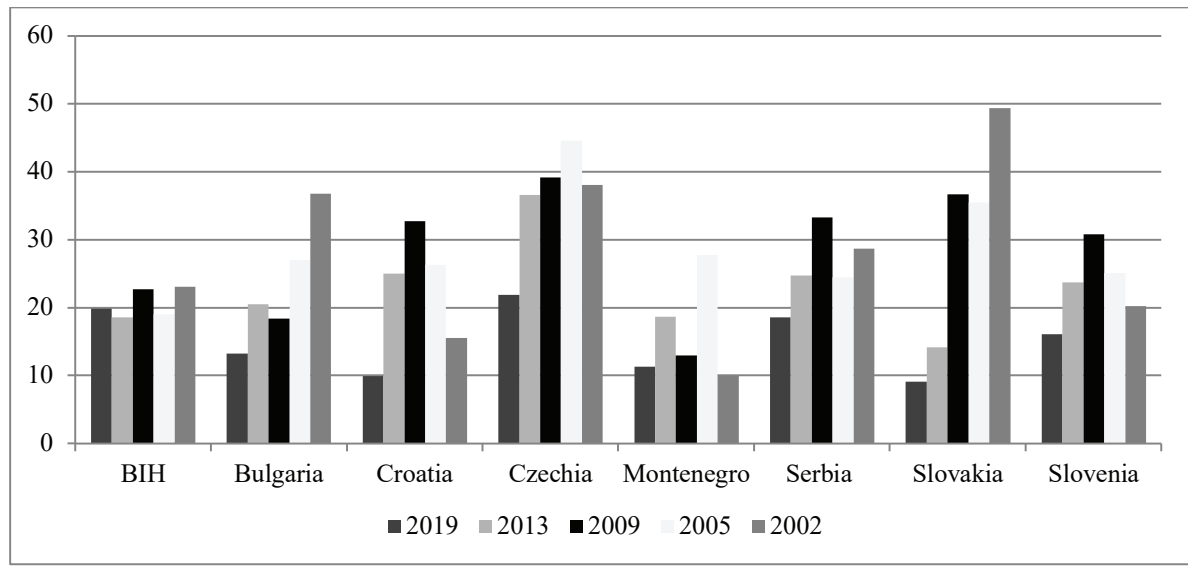

Source: author based on BEEPS data.

It has to be emphasized that respondents' general willingness to report incidence might vary between the countries and within a country in time. This can be related to other issues, such as general business climate or cultural differences between the countries. However, also the composition of the sampled firms changes within a country over time, and although every effort has been made to ensure sample representativeness it could still be the case that in some period sampled firms were more responsive to specific questions.

Regardless of these potential constraints for the interpretation of the data, Figure 1 reveals that in general most of the analyzed countries experienced a decrease in business exposure to criminal activity in the $2002-2019$ period. ${ }^{29}$ The decrease has been most notable in Slovakia, while improvements are relatively minor in Bosnia and Herzegovina. When it comes to the most recent observation (for the year 2019), the highest share of firms exposed to crime was in Czechia, followed by Bosnia and Herzegovina and Serbia. The lowest share was in Slovakia and Croatia. Thus, it can be concluded that although some

29 Eurostat provides statistics on recorded offences based on countries police data, but not restricted to the victims from business sector. The most similar offence in the database is theft. The Eurostat data show that in the 2009-2018 period theft per inhabitant is decreasing in most analysed countries, with the exception of Serbia and Bosnia and Herzegovina, the data for the latter country not being available (https://ec.europa.eu/eurostat/web/crime/data/database). 
positive trends can be identified during the post-transition period, enterprises are differently affected by the crime in analyzed economies.

To assess the effect of crime on business activity, we investigate if the exposure to criminal activity has affected the firms' expectations for their future business activity. Specifically, respondents were asked whether they expect their firm's total sales to increase, decrease, or stay the same in the next fiscal period. The analysis is performed for the year 2019, and subsequently the expectations of the respondents have most certainly not been fulfilled due to the global pandemic outburst in 2020. However, at the time of the Survey, the economies of the analyzed countries were following a stable growth path and the respondents' answers are based on the assumption that no other systematic effects are interfering with their assessment of the upcoming business period. The data in Figure 2 for each country shows the difference in responses between those firms experiencing direct losses from crime activity (marked _*) and those who were not exposed to criminal activity.

Figure 2 Firms' expectations about their future growth, 2019

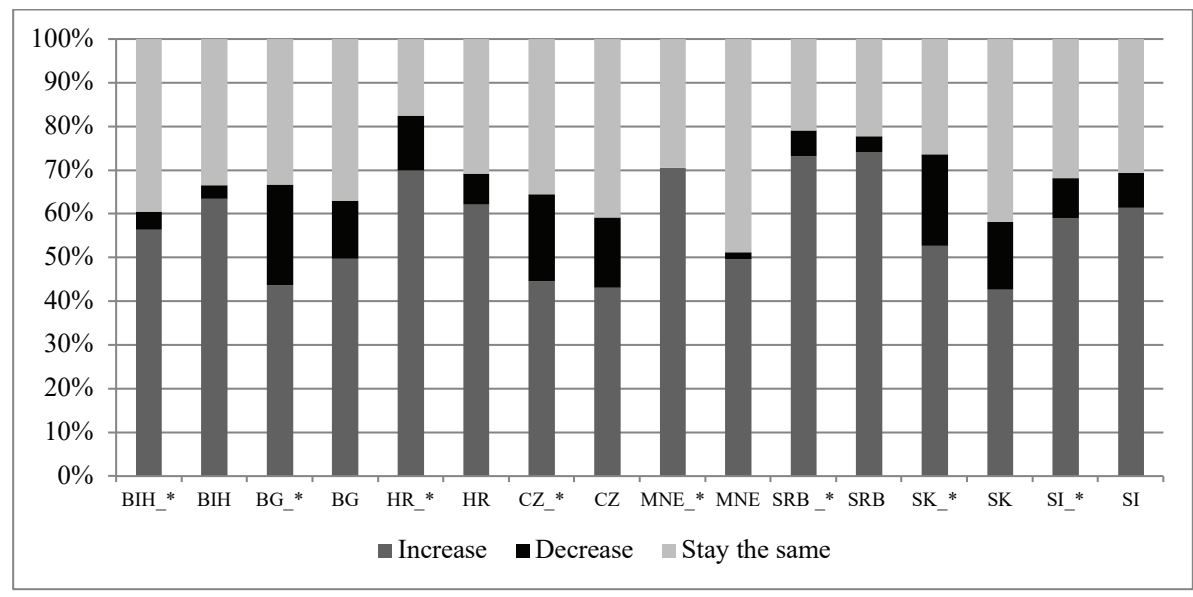

Source: author based on BEEPS data.

The data in Figure 2 shows that most respondents were rather optimistic regarding the future prospects of their firms. The firms with crime exposure are in general more likely to expect a decrease in their sales in the next fiscal period. But, it can also be noticed that - contrary to initial expectations - in some countries, those who experienced crime losses are more optimistic about the possibility to increase sales (Slovakia, Montenegro, and Croatia). It could be argued that in some countries entrepreneurs faced with adverse conditions show certain resilience. 
This issue is further quantitatively assessed. A multinomial logit model has been specified with a dependent variable capturing firms' expectations about future sales (staying the same being the base option). This approach somewhat reduces the usual problem of reverse causality, ${ }^{30}$ because it is not very likely that the more optimism of the entrepreneurs will affect their likelihood of being affected by the crime. The independent variables include:

- the key variable of interest is related to crime exposure, it is a binary variable taking value 1 if a firm experienced losses as a result of theft, robbery, vandalism, arson on its premises or from Internet hacking or fraudulent Internet transactions,

- size and age of the firm. While larger and older firms might be more strategically oriented towards continuing business operation, ${ }^{31}$ it is often small and young firms that are in a sink or swim situation. The majority of small firms do not grow rapidly, and those that do experience high growth, experience it in discrete episodes, rather than continuously. ${ }^{32}$ Islam, ${ }^{33}$ however, argues that the relationship depends on whether the economic growth is absorbed by large or small firms. Whatever type of firm is able to expand more during the boom phase in the economy, that type of firm is also increasing its ability for protection against theft and vandalism. The age is defined as the number of years since foundation, while three dummy variables represent the size (the middle-sized firm being the reference value).

- foreign ownership is usually considered through the effect the criminal activity has on foreign direct investment attraction. ${ }^{34}$ It is generally assumed that crime discourages investors from investing in certain areas. There is no

30 In similar studies exploring the effect of crime on business performance enterprise sales (growth) are considered as a dependent variable. For example, Gaviria, A.: Assessing the effects of corruption and crime on firm performance: evidence from Latin America, Emerging Markets Review, 3(2) 2002, p. 245-268; Islam, A.: Economic growth and crime against small and medium sized enterprises in developing economies, Small Business Economics, 43(3) 2014, p. 677-695. It makes it relatively harder to assess whether crime affects sales or a decrease in sales leads to more crime due to a related decrease in employment opportunities.

31 Orser, B.J. et al.: Performance, firm size, and management problem solving, Journal of Small Business Management, 38(4) 2000, p. 42-58.

32 Mason, G. et al:: Sources of Labour Productivity Growth at Sector Level in Britain, 19982007: A Firm-level Analysis, Review of Economics and Institutions, 7(2) 2016, Article 3.

33 Islam, A.: Economic growth and crime against small and medium sized enterprises in developing economies, Small Business Economics, 43(3) 2014, p. 679.

34 Brown, L.; Hibbert, K.: The Incidence of Crime on Industry-Level Foreign Direct Investment: An Assessment of OECD Member Countries, Social Science Quarterly, 100(4) 2019, p.122. 
reason that firms with existing foreign ownership structures will be more or less targeted by criminal activity unless we a priori assume that foreign firms will invest more in the security because they either carry on practices from their home countries or perceive the country they invest in more risky. When it comes to business performance, foreign corporate ownership is considered to exert positive influence. ${ }^{35}$ In the estimates, a dummy variable taking value 1 if the firm has any positive share of foreign ownership in the ownership structure.

- two characteristics of the firm's manager are included: sex and experience. It has been documented that in some cases inclusion of a female in top management improves firm performance ${ }^{36}$ so we include a binary variable taking value 1 if the top manager is female. Manager's experience is measured by the number of years working in the specific sector. It is assumed that a manager's experience is positively associated with the firm performance, the mechanism being the transfer of specific knowledge in firm operations.

- characteristics of the market a firm operates in have been captured by two indicators: whether a firm does business with the government or if it participates in international markets, both have been captured by relevant dummy variables. The importance of participation in international markets for firm performance has been documented by many empirical studies. ${ }^{37}$ The government contracts are usually for longer-lasting projects, so the respondents whose firms managed to secure government contracts might be more optimistic about the future sales growth. On the other hand, securing of government contract might also suggest certain political connectedness. ${ }^{38}$ This latter argument could be of particular importance for post-transition economies, where political ties to business might be more widespread.

- capacity utilization is a measure of firm current status, but the expected effect on a firm manager's perception of future firm growth is not straightforward. If the firm is already working with full capacity, it could be argued that there are no additional potentials for growth in the short run. Yet, by

35 Douma, S. et al:: Foreign and domestic ownership, business groups, and firm performance: evidence from a large emerging market, Strategic Management Journal, 27(7) 2016, p. 642-643.

36 Dezsö, C.L.; Ross, D.G.: Does female representation in top management improve firm performance? A panel data investigation, Strategic Management Journal, 33(9) 2012, p. 1072 1089.

37 Wagner, J.: International trade and firm performance: a survey of empirical studies since 2006, Review of World Economics, 148(2) 2016, p. 235-267.

38 Niessen, A.; Ruenzi, S.: Political Connectedness and Firm Performance: Evidence from Germany, German Economic Review, 11(4) 2010, p.441-464. 
changing the market structure or by increasing the margins, a firm can still achieve higher sales. Similarly, if a firm already is beneath its optimal capacity, it could be a sign of decreasing demand and it could be more likely that the manager expects a further decline in sales.

The model has been estimated for the sample covering all analyzed countries. In that case, a dummy for each country has been included in a specification (Czechia being the reference country) in order to capture other country-specific factors. The results are presented in the following section.

\section{RESULTS AND DISCUSSION}

The estimates have been performed based on the data for the most recent year 2019. Relative risk ratios of respondents believing that their firm's sales will increase in the next period relative to staying the same, or that the sales will decrease relative to staying the same are present in Table 1.

Table 1 Predicting future sales expectations, relative risk ratios to base (stay the same)

\begin{tabular}{|l|c|c|}
\hline \multirow{2}{*}{ Variables } & \multicolumn{2}{|c|}{ Future sales expectations } \\
\cline { 2 - 3 } & Increase & Decrease \\
\hline \multirow{2}{*}{ Constant } & -0.0427 & -0.539 \\
& $(0.375)$ & $(0.573)$ \\
\hline \multirow{2}{*}{ Capacity utilization } & 0.00139 & $-0.0100^{* *}$ \\
& $(0.00334)$ & $(0.00501)$ \\
\hline \multirow{2}{*}{ International market } & 0.167 & 0.281 \\
& $(0.143)$ & $(0.242)$ \\
\hline \multirow{2}{*}{ Manager experience } & 0.00553 & 0.00600 \\
& $(0.00604)$ & $(0.0101)$ \\
\hline \multirow{2}{*}{ State contract } & -0.182 & $-0.636^{*}$ \\
& $(0.170)$ & $(0.353)$ \\
\hline \multirow{2}{*}{ Firm age } & $-0.00601^{*}$ & -0.00491 \\
& $(0.00321)$ & $(0.00626)$ \\
\hline \multirow{2}{*}{ Female manager } & -0.0139 & 0.395 \\
& $(0.162)$ & $(0.242)$ \\
\hline \multirow{2}{*}{ Foreign ownership } & $-0.397 * *$ & 0.0708 \\
\hline \multirow{2}{*}{ Large firm } & $(0.181)$ & $-0.315)$ \\
\hline \multirow{2}{*}{ Small firm } & 0.259 & $(0.303)$ \\
\hline
\end{tabular}




\begin{tabular}{|l|c|c|}
\hline \multirow{2}{*}{ Variables } & \multicolumn{2}{|c|}{ Future sales expectations } \\
\cline { 2 - 3 } & Increase & Decrease \\
\hline \multirow{2}{*}{ Crime loses } & 0.311 & $0.796^{* * *}$ \\
& $(0.201)$ & $(0.285)$ \\
\hline \multirow{2}{*}{ Bosnia and Herzegovina } & $0.754^{* * *}$ & -15.30 \\
& $(0.254)$ & $(586.7)$ \\
\hline \multirow{2}{*}{ Bulgaria } & $0.399^{* *}$ & 0.247 \\
& $(0.189)$ & $-0.272)$ \\
\hline \multirow{2}{*}{ Croatia } & $0.681^{* * *}$ & $(0.418)$ \\
\hline \multirow{2}{*}{ Montenegro } & $(0.231)$ & -15.81 \\
& 0.157 & $(773.2)$ \\
\hline Serbia & $(0.299)$ & -0.823 \\
& $1.474^{* * *}$ & $(0.655)$ \\
\hline Slovakia & $(0.285)$ & -0.335 \\
\hline \multirow{2}{*}{ Slovenia } & 0.0498 & $(0.319)$ \\
\hline Observations & $(0.212)$ & $(0.409)$ \\
\hline Pseudo $\mathrm{R}^{2}$ & $0.846^{* * *}$ & \multicolumn{2}{|c|}{} \\
\hline Wald chi ${ }^{2}(34)$ & $(0.231)$ & $165.4 * * *$ \\
\hline Log likelihood & \multicolumn{2}{|c|}{0.0648} \\
\hline
\end{tabular}

Source: author's estimates based on BEEPS.

Notes: standard errors in parentheses, $* * * \mathrm{p}<0.01, * * \mathrm{p}<0.05, * \mathrm{p}<0.1$

The estimates reveal that respondents are significantly more likely to expect a decrease in future sales (relative to stay the same) if they experienced losses attributed to crime. The marginal effect is also significant and reveals that respondents who experienced losses attributed to crime are 5.9\% more likely to expect a decrease in their future sales (in comparison to maintain the same level of sales). So, the results presented here are in line with previous studies documenting the detrimental effect of exposure to crime for business activity.

Respondents are also more likely to expect a decrease in future sales if they already have lower capacity utilization, have not secured a government contract and the firm is small. These results are expected. The results for capacity utilization seem to reflect that those firms who are already decreasing their productive capacity are more likely to expect further decline. Furthermore, small firms frequently do not have the capacity to maintain their presence on the market, while having a government contract seems to act as insurance against sales decrease (although also not a guarantee for a firm's sales growth). 
The crime losses are not significant predictors for the increase in future sales (relative to maintain the same sales level). This shows that at least for some firms who were exposed to crime other factors are more important and enable the entrepreneurs to overcome the difficulties arising from crime losses. It seems that older firms and those with some percentage of foreign ownership are less likely to expect future sales growth (relative to staying the same). It could be argued that those firms are more likely to adopt relatively conservative business strategies even for the cases when they expect growth of their future sales.

The results also confirm significant differences among the analyzed countries, at least when it comes to predicting future firms' growth. Thus, specific conditions in each country are a strong predictor of whether an entrepreneur will be optimistic about the growth of a firm's sales in the near future. The results seem to suggest that even in the situation where firms are affected by criminal activity if other factors of beneficial business climate are supporting entrepreneurship, the firms are able to overcome difficulties arising from crime exposure. These results are not universal and should not be considered relevant for regions with very high crime rates. However, for the post-transition European economies, improving other obstacles to firm growth should be considered a priority. At the same time, it does not mean that firms should be left without support in case they are targeted by criminal activity. However, well-defined policy measures envisaged within the national security standards are probably sufficient and no specific policy measures within the economic policies domain should be considered based on the results presented in this paper.

\section{CONCLUSIONS}

The paper explores the effect of crime exposure on the expectation of business performance in post-transition economies. Based on the World Bank Enterprise Survey, the issue has been explored for eight post-transition European economies: Bosnia and Herzegovina, Bulgaria, Croatia, Czechia, Montenegro, Serbia, Slovakia, and Slovenia. Since economic aspects of crime are seldom analyzed for this specific group of countries, the present analysis complements existing literature. The issue is of particular importance considering that reducing business obstacles enables entrepreneurship growth and catching up of the analyzed EU members and candidates.

Instead of addressing the traditional indicators of business performance, such as sales or employment growth, the analysis is focused on future expectations of firm growth. Results show that respondents in firms who suffered crime losses are in general more likely to expect a decrease in their sales in the next fiscal period. But, it has been also established that - contrary to initial expectations 
- in some countries, those who experienced crime losses are more optimistic about the possibility to increase sales (Slovakia, Montenegro, and Croatia).

The estimates of the multinomial model have confirmed results obtained in previous studies that crime exposure negatively affects business activity. However, the effect was only significant for those who expect decreases in their activity - respondents who experienced losses attributed to crime are $5.9 \%$ more likely to expect a decrease in their future sales (in comparison to maintain the same level of sales). Respondents who are optimistic about their future growth potential seem to be able to overcome their crime experience more easily as in their case crime exposure is not a significant predictor.

An important limitation of the present study is that it does not differentiate between different types of crime because of the data constraints. Since proper policy measures can be developed only for a specific type of criminal activity, future research endeavors should envisage a more detailed analysis of the crimes affecting enterprises.

\section{LITERATURE}

1. Albanese, G.; Marinelli, G.: Organized crime and productivity: Evidence from firm-level data, Rivista Italiana degli Economisti, 18 2013, p. 367-394.

2. Allum, F.; Sands, J.: Explaining organized crime in Europe: Are economists always right?, Crime, Law and Social Change, 41(2) 2004, p. 133-160.

- DOI: https://doi.org/10.1023/B:CRIS.0000016223.49968.17

3. Amin, M.: Crime, Security and Firms in Latin America (Short Note), [http:// works.bepress.com/mohammad_amin/11], accessed 03/06/2020.

4. Amin, M.: Crime and Security in the Eastern Europe and Central Asia Region, Enterprise surveys note series; no. 15. Crime Washington, D.C.: World Bank Group. [http://documents.worldbank.org/curated/en/655801468254089683/Crime-and-security-in-the-Eastern-Europe-and-Central-Asia-region], accessed 15/05/2020.

5. Baldwin, J. R.; Brown, W.M.; Rigby, D. L.: Agglomeration economies: Microdata panel estimates from Canadian manufacturing, Journal of Regional Science, 50(5) 2010, p. 915-934.

- DOI: https://doi.org/10.1111/j.1467-9787.2010.00675.x

6. Barnes, P.; Oloruntoba, R.: Assurance of Security in Maritime Supply Chains: Conceptual Issues of Vulnerability and Crisis Management, Journal of International Management, 11(4) 2005, p. 519-540.

- DOI: https://doi.org/10.1016/j.intman.2005.09.008 
7. Becker, G.: Crime and Punishment: An economic approach, Journal of Political Economy, 76(1) 1968, p. 160-217.

- DOI: https://doi.org/10.1086/259394

8. Ben-Yishay, A.; Pearlman, S.: Crime and Microenterprise Growth: Evidence from Mexico, World Development, 56 2014, p. 139-152.

- DOI: https://doi.org/10.1016/j.worlddev.2013.10.020

9. Bjelalac, $\check{Z}$.; Bingulac, N.: Impact of corruption on the process of Eurointegration of Serbia, Journal of Eastern-European Criminal Law, 1 2016, p. 208-223.

10. Brown, L.; Hibbert, K.: The Incidence of Crime on Industry-Level Foreign Direct Investment: An Assessment of OECD Member Countries, Social Science Quarterly, 100(4) 2019, p. 1228-1240.

- DOI: https://doi.org/10.1111/ssqu.12624

11. Cho, H.; Choi, S.; Lee, W.-J.; Yang, S.: Regional crime rates and corporate misreporting, Spanih Journal of Finance and Accounting/Revista Española Financiación Contabilidad, 49(1) 2020, p. 94-123.

- DOI: https://doi.org/10.1080/02102412.2019.1582194

12. Czinkota, M.R.; Knight, G.A.; Liesch, P.W.; Steen, J.: Terrorism and International Business: A Research Agenda, Journal of International Business Studies, 41(5) 2010, p. 826-843.

- DOI: https://doi.org/10.1057/jibs.2010.12

13. Daniele, V.; Marani, U.: Organized Crime, the Quality of Local Institutions and FDI in Italy: A Panel Data Analysis, European Journal of Political Economy, 27(1) 2011, p. 132-142.

- DOI: https://doi.org/10.1016/j.ejpoleco.2010.04.003

14. Dezsö, C.L.; Ross, D.G.: Does female representation in top management improve firm performance? A panel data investigation, Strategic Management Journal, 33(9) 2012, p. 1072-1089.

- DOI: https://doi.org/10.1002/smj.1955

15. Douma, S.; Rejie, G.; Kabir, R.: Foreign and domestic ownership, business groups, and firm performance: evidence from a large emerging market, Strategic Management Journal, 27(7) 2016, p. 637-657.

- DOI: https://doi.org/10.1002/smj.535

16. Freeman, R.B.: The Economics of Crime, in: Ashenfelter, O.C.; Card, D. (eds): Handbook of Labor Economics, Volume 3, Part C, Amsterdam, Netherlands: North Holland Publishers, 1999, p. 3529-3571.

- DOI: https://doi.org/10.1016/S1573-4463(99)30043-2

17. Gaviria, A.: Assessing the effects of corruption and crime on firm performance: evidence from Latin America, Emerging Markets Review, 3(2) 2002, p. 245-268.

- DOI: https://doi.org/10.1016/S1566-0141(02)00024-9 
18. Greenbaum, R.T.; Dugan, L.; LaFree, G.: The Impact of Terrorism on Italian Employment and Business Activity, Urban Studies 44(5/6) 2007, p. 1093-1108.

- DOI: https://doi.org/10.1080/00420980701255999

19. Hignett, K.: Organised Crime in East Central Europe: The Czech Republic, Hungary and Poland, Global Crime, 6(1) 2004, p. 70-83.

- DOI: https://doi.org/10.1080/1744057042000297981

20. Islam, A.: Is There a Gender Bias in Crime Against Firms in Developing Economics?, Women's Studies International Forum, 37 2013, p. 1-15.

- DOI: https://doi.org/10.1016/j.wsif.2013.01.005

21. Islam, A.: Economic growth and crime against small and medium sized enterprises in developing economies, Small Business Economics, 43(3) 2014, p. 677-695.

- DOI: https://doi.org/10.1007/s11187-014-9548-6

22. Jaitman, L. (ed.): The cost of crime and violence: new evidence and insights in Latin America and the Caribbean, New York: Inter-American Development Bank, 2017.

- DOI: https://doi.org/10.18235/0000617

23. Kelly, M.: Inequality and Crime, Review of Economics and Statistics, 82 (4) 2000, p. 540-554.

24. Krkoska, L.; Robeck, K.: The impact of crime on the enterprise sector: Transition versus non-transition countries, EBRD Working Paper No. 97, 2006.

25. Lotspeich, R.: Crime in transition economies, Europe-Asia Studies, 47(4) 1995, p. 555-591.

- DOI: https://doi.org/10.1080/09668139508412276

26. Los, M.: Crime in transition: The post-communist state, markets and crime. Crime, Law and Social Change, 40(2-3) 2003, p. 145-169.

- DOI: https://doi.org/10.1023/A:1025788705613

27. Mason, G.; Robinson, C.; Bondibene, C.R.: Sources of Labour Productivity Growth at Sector Level in Britain, 1998-2007: A Firm-level Analysis, Review of Economics and Institutions, 7(2) 2016, Article 3.

- DOI: https://doi.org/10.5202/rei.v7i2.221

28. Niessen, A.; Ruenzi, S.: Political Connectedness and Firm Performance: Evidence from Germany, German Economic Review, 11(4) 2010, p. 441-464.

- DOI: https://doi.org/10.1111/j.1468-0475.2009.00482.x

29. Orser, B.J.; Hogarth-Scott, S.; Riding, A.L.: Performance, firm size, and management problem solving, Journal of Small Business Management, 38(4) 2000, p. 42-58.

30. PwC (2020). Fighting fraud: A never ending tale. PwC's Global Economic Crime and Fraud Survey. [https://www.pwc.com/gx/en/forensics/gecs-2020/pdf/globaleconomic-crime-and-fraud-survey-2020.pdf], accessed 10/08/2020. 
31. Rocque, M.; Saunoris, J.W.; Marshall, E.C.: Revisiting the Relationship Between the Economy and Crime: The Role of the Shadow Economy, Justice Quarterly, 36(4) 2019, p. 620-655.

- DOI: https://doi.org/10.1080/07418825.2018.1424230

32. Rosenthal, S.; Ross, A.: Violent Crime, Entrepreneurship, and Cities, Journal of Urban Economics, 67(1) 2010, p. 135-149.

- DOI: https://doi.org/10.1016/j.jue.2009.09.001

33. Spendzharova, A.B.; Vachudova, M.A.: Catching Up? Consolidating Liberal Democracy in Bulgaria and Romania after EU Accession, West European Politics, 35(1) 2012, p. 39-58.

- DOI: https://doi.org/10.1080/01402382.2012.631312

34. Wagner, J.: International trade and firm performance: a survey of empirical studies since 2006, Review of World Economics, 148(2) 2016, p. 235-267.

- DOI: https://doi.org/10.1007/s10290-011-0116-8 